\title{
OLEIC ACID - HEALTH BENEFITS AND STATUS IN PLASMA PHOSPHOLIPIDS IN THE SERBIAN POPULATION
}

Aleksandra Arsic ${ }^{1}$, Ana Stojanovic ${ }^{2}$, Milena Mikic ${ }^{3}$

${ }^{1}$ Centre of Research Excellence in Nutrition and Metabolism, Institute for Medical Research, University of Belgrade, Belgrade, Serbia ${ }^{2}$ Clinical Hospital Center "Bežanijska Kosa” Belgrade, Serbia

${ }^{3}$ Department of Bromatology, Faculty of Pharmacy, University of Belgrade, Serbia

\section{OLEINSKA KISELINA-UTICAJ NA ZDRAVLJE I STATUS U FOSFOLIPIDIMA PLAZME U SRPSKOJ POPULACIJI}

Aleksandra Arsić ${ }^{1}$, Ana Stojanović 2, Milena Mikić ${ }^{3}$

${ }^{1}$ Centar izuzetne vrednosti u oblasti istraživnja ishrane i metabolizma, Institut za medicinska istraživanja, Univerzitet u Beogradu, Beograd, Srbija ${ }^{2}$ Kliničko-bolnički centar "Bežanijska kosa”, Beograd, Srbija,

${ }^{3}$ Ketedra za bromatologiju, Farmaceutski fakultet, Univerzitet u Beogradu, Beograd, Srbija

Received / Primljen: 21. 06. 2017.

Accepted / Prihvaćen: 08. 07. 2017.

\section{ABSTRACT}

Oleic acid has many beneficial effects on human health. One of the main dietary sources of oleic acid is olive oil. Non-Mediterranean European countries, including Serbia, have low habitual olive oil consumption, but other vegetable oils also contain different amounts of oleic acid. In infants and young children milk is the most important source of fatty acids, including oleic acid. Furthermore, fatty acid composition of plasma phospholipids reflects dietary intake and fatty acid metabolism. In patients with serious chronic diseases fatty acid status is altered independently on the intake. Here we reviewed status of oleic acid in healthy persons as well as in patients with different chronic diseases in Serbia.

Keywords: plasma phospholipids, oleic acid, olive oil

\section{SAŽETAK}

Oleinska kiselina ima ima višestruke pozitivne efekte na život $i$ zdravlje ljudi. Jedan od glavnih izvora oleinske kiseline je maslinovo ulje. Evropske zemlje, koje ne pripadaju mediteranskoj regiji, među kojima je i Srbija, retko koriste maslinovo ulje u ishrani, ali i druga biljna ulja sadrže oleinsku kiselinu u različitom procentu. Kod odojčadi i dece mladeg uzrasta, mleko je najvažniji izvor masnih kiselina, uključujući $i$ oleinsku. Dijetetski unos masnih kiselina $i$ njihov metabolizam u telu, odražava masnokiselinski sastav u fosfolipidima plazme. Kod pacijenata sa teškim hroničnim oboljenjima, masnokiselinski sastav je promenjen nezavisno od unosa. U ovom radu je prikazan status oleinske kiseline kod zdravih osoba, kao i kod pacijenata sa različitim hroničnim oboljenjima u Srbiji.

Ključne reči: fosfolipidi plazme, oleinska kiselina, maslinovo ulje

\section{ABBREVIATIONS}

FA- fatty acid

IDL- intermediate-density lipoprotein HDL- high-density lipoproteines MUFA - monounsaturated fatty acid
OA- oleic acid

PUFA- polyunsaturated fatty acid

SFA- saturated fatty acid

VLDL- very-low-density lipoprotein

\section{OLIVE OIL AS A KEY COMPONENT OF MEDITERRANEAN DIET}

Numerous epidemiological, clinical and experimental research have shown that consumption of Mediterranean diet rich in olive oil has a profound influence on a number of health outcomes, including obesity, metabolic syndrome, cardiovascular disease and diabetes mellitus (1). Intensive olive oil intake is inversely associated with both systolic and diastolic blood pressure (2), and with stroke incidence in elderly populations (3). A major component that is responsible for beneficial properties of olive oil is oleic acid (OA). Olive oil contains up to $80 \%$ monounsaturated fatty acids (MUFA), mostly in the form of OA, relatively low content of saturated (SFA) and polyunsaturated fats (PUFA), but also several antioxidant components, including phenolic compounds that could partially account 
for the observed healthful effects of the Mediterranean diet (4). Non-Mediterranean European countries, including Serbia, have low habitual olive oil consumption. However, olive oil is not the only source of OA, it is also a component of other vegetable oils, nuts and animal products $(5,6)$, although its concentration depends on the type of food, as well as on the region.

Besides the favorable effects of oleic acid intake in adults, it is also essential in infants and children nutrition. $\mathrm{OA}$ is a component of tissues and membranes, and a major fatty acid (FA) component of brain myelin phospholipid, which is mainly formed during the two years after birth (7). Since OA is rapidly deposited during myelination, its proportion in brain total lipids increases with progressive central nervous system myelination (8). Thus intake of OA is of a great importance in post-natal life. In infants and young children milk is the most important source of fatty acids, including OA. Several epidemiological studies reported different content of OA and other FA in human colostrum (9), transitional and mature milk (10-12), suggesting that FA composition of breast milk is markedly influenced by geographic differences in maternal dietary composition. The similar situation has been shown in cow's milk samples, as various interactions were found among diet type, cow type and altitude, indicating that a combination of these factors contributes to the characteristic FA profile of the respective milk (13).

Fatty acids have been traditionally considered as precursors for the biosynthesis of macromolecules and as a source of energy, as well as constituents of cellular membranes. However, emerging evidences from several lines suggest that dietary FA serve multiple function in the body, and are linked not only to health promotion, but also to disease pathogenesis. Therefore, the choice of dietary FA could markedly influence overall health in humans. Depending on the dietary intake of FA, blood phospholipids' FA composition will change (14). In healthy people, the FA profile of the serum/plasma phospholipid is an indirect biomarker of the average dietary FA intake during the last 3 to 6 weeks, while the composition of erythrocyte phospholipids reflects the intake during the preceding months $(15,16)$. Nevertheless, a number of physiological and pathologic conditions can influence the FA status in blood. Here we reviewed status of OA in plasma phospholipids of healthy people of different ages, in professional athletes and in patients with chronic diseases in Serbia.

\section{OLEIC ACID STATUS IN PLASMA PHOSPHOLIPIDS}

\section{Apparently healthy subjects}

Several papers reported FA status in apparently healthy subjects in Serbia $(14,17-22)$. Their content of OA in plasma phospholipids is presented in Table 1 . As it can be seen in the Table, healthy people have similar level of OA in plasma from birth to older ages. Slightly lower level of OA was found in young adults, but it can be attributed to their specific dietary intake which mostly includes fast food with low level of OA.

\section{Elite athletes}

The status of OA in plasma phospholipids of elite athletes is displayed in Table 2. In comparison to sedentary healthy subjects, athletes mostly have lower levels of OA.

Table 1. The content oleic acid in plasma phospholipids in apparently healthy subjects in Serbia

\begin{tabular}{|lllll}
\hline Author, year (ref No) & Sample size & Gender (M/F) & Mean age & mol\% of OA \\
\hline Arsić et al., 2012 (17) & 12 & n.a. & $\begin{array}{l}\text { At birth } \\
\text { (34-36 weeks of gestation) }\end{array}$ & $11.91 \pm 0.73$ \\
\hline Arsić et al., 2012 (20) & 14 & $0 / 14$ & $23.67 \pm 1.56$ & $9.03 \pm 1.03$ \\
\hline Tepšić et al, 2009 (14) & 16 & $16 / 0$ & $24.0 \pm 3.0$ & $11.03 \pm 1.50$ \\
\hline Tepšić et al, 2013 (19) & 19 & $19 / 0$ & $24.44 \pm 3.40$ & $10.46 \pm 1.66$ \\
Cvetković et al., 2010 (18) & 29 & $15 / 14$ & $53(23-71)$ & $11.70 \pm 1.79$ \\
\hline Ristić et al., 2006 (22) & 29 & $17 / 12$ & $55 \pm 9$ & $11.71 \pm 1.24$ \\
\hline Popović et al., 2009(21) & 15 & $12 / 3$ & $60(54-68)$ & $11.85 \pm 1.69$ \\
\hline
\end{tabular}

Table 2. The content oleic acid in plasma phospholipids of elite athletes in Serbia

\begin{tabular}{|c|c|c|c|c|c|}
\hline Author, year (ref No) & Type of sport & Sample size & Gender & Mean age & $\mathrm{mol} \%$ of OA \\
\hline Petrovic et al., 2016 (23) & Handball & 17 & $\mathrm{~F}$ & $17.2 \pm 0.93$ & $7.81 \pm 0.49$ \\
\hline Petrovic et al., 2016 (23) & Handball & 15 & M & $18.5 \pm 1.06$ & $8.49 \pm 0.97$ \\
\hline Tepšić et al, 2009 (14) & Basketball & 23 & M & $21 \pm 4$ & $10.69 \pm 1.00$ \\
\hline Arsić et al., 2012 (20) & Football & 19 & $\mathrm{~F}$ & $21.19 \pm 2.45$ & $10.42 \pm 1.21$ \\
\hline Arsić et al., 2012 (20) & Waterpolo & 15 & $\mathrm{~F}$ & $21.71 \pm 4.5$ & $8.85 \pm 1.56$ \\
\hline Tepšić et al, 2013 (19) & Box & 16 & M & $22.41 \pm 3.28$ & $14.06 \pm 1.50$ \\
\hline Tepšić et al, 2009 (14) & Football & 24 & M & $24 \pm 5$ & $11.01 \pm 0.95$ \\
\hline
\end{tabular}


Table 3. The content oleic acid in plasma phospholipids in patients with different diagnoses in Serbia

\begin{tabular}{|c|c|c|c|c|c|}
\hline Author, year (ref No) & Diagnosis & Sample size & Gender (M/F) & Mean age & mol\% of OA \\
\hline Ristić et al., 2006 (22) & hemodyalized & 37 & $21 / 16$ & $52 \pm 10$ & $13.05 \pm 2.21$ \\
\hline Ristić-Medić et al., 2009 (24) & hyperlipidemia & 78 & $25 / 53$ & $56(45-65)$ & $11.20 \pm 1.0$ \\
\hline Ristić-Medić et al., 2006 (25) & Type 2 diabetes & 28 & n.a. & $57 \pm 7$ & $10.46 \pm 2.31$ \\
\hline Cvetković et al., 2010 (18) & non-Hodgkin lymphoma & 47 & $26 / 21$ & $57(19-74)$ & $13.8 \pm 1.4$ \\
\hline Popović et al., 2009 (21) & obstructive jaundice & 13 & $10 / 3$ & $59(54-68)$ & $14.31 \pm 2.19$ \\
\hline Ristić-Medić et al., 2013 (26) & Alcoholic liver cirrhosis & 20 & $18 / 2$ & $62(46-72)$ & $18.83 \pm 4.54$ \\
\hline Veselinovic et al., 2017 (27) & Rheumatoid arthritis & 60 & $0 / 60$ & $63.1 \pm 9.6$ & $8.64 \pm 1.03$ \\
\hline
\end{tabular}

In particular handball players, both male and female, and female water polo players $(14,20,23)$. On the contrary, boxers had significantly higher levels of OA, but their general fatty acid status is altered (19).

\section{Chronic non-communicable diseases}

Since FA profiles in plasma phospholipids also depend on the metabolism, they are often altered in chronic diseases. Table 3 presents the OA proportions in patients with different diagnoses. It seems that metabolic disorders, such as hyperlipidemia (24) and diabetes mellitus type 2 (25) do not affects metabolism of OA and its level remain similar as in the control group. Patients with non-Hodgkin lymphoma (18) and patients on hemodialysis (22) had higher levels of OA (13-14 mol\%). Serious liver diseases, such as obstructive jaundice (21), and in particular alcoholic liver cirrhosis (26), markedly increased level of OA in plasma phospholipid, while in contrast rheumatoid arthritis (27) decreased OA in comparison to control subjects. The observed changes are unlikely to be a consequence of increased (or in patients with rheumatoid arthritis decreased) intake, but rather of altered activity of delta- 9 desaturase. The reasons for these alterations remain to be clarified.

\section{HEALTH BENEFITS OF OLEIC ACID}

Oleic acid is the major component that is responsible for health benefits of the Mediterranean diet, rich in vegetables, fruits and particularly olive oil (28). It has been shown that diets with OA are associated with a decreased risk of coronary heart disease, cardio-metabolic risk, obesity, type 2 diabetes and hypertension $(29,30)$. Observational studies from Mediterranean cohorts have suggested that dietary MUFA, in particular OA, may be protective against stroke (3), age-related cognitive decline and $\mathrm{Al}$ zheimer's disease (30). In addition, insulin sensitivity is relatively impaired by diets that are low in oleic acid, or rich in trans MUFA or saturated palmitic acid (31). Rising evidence exists that saturated palmitic acid causes insulin resistance via stimulation of inflammatory signaling and production of cytosolic lipid compounds (diacylglycerol and ceramide). OA acts in an opposite direction, suggesting that dietary or pharmacologic intervention that facilitate transport of FA into the mitochondria would be beneficial (32). Moreover, substitution of dietary saturated fat by OA and/or PUFA has been described to reduce the cardiovascular risk by reducing blood lipids, mainly cholesterol, LDL-cholesterol and triglycerides $(33,34)$. Nevertheless, Pedersen et al. reported that in healthy men the olive oil diet resulted in higher concentrations of VLDL, IDL, and LDL particles (number and lipid content) than the rapeseed oil and sunflower oil diets (35).

Furthermore, the authors did not find any differences between proportion of OA in serum phospholipids (as a biomarker of dietary intake) of patients with hyperlipidemia or T2D and healthy controls (25). The percentage of OA in adults in this study varied from $10.3 \%$ in young females, to $11.9 \%$ in older male participants. The results from other studies showed a strong ecological correlation between olive oil intake and oleic acid in plasma phospholipids (36). For instance, a multicenter European cross-sectional study found that participants from northern countries had lower intake of olive oil and lower OA in plasma phospholipids (9.4-10.5\%) than people from Spain, Italy and Greece (11.2-12.7\%) (36), while another study reported $9.5-9.8 \%$ of OA in plasma phospholipids of female and male subjects in Australia, respectively (37).

Recent findings suggest potential protective effects of OA on the promotion and progression of several human cancers. Several case-control and cohort studies have shown that OA and olive oil are associated with a reduction in the risk of cancer, mainly breast, colorectal and prostate cancer (38). Although underlying mechanism requires further investigation, protective action on cancer may be mediated through several mechanisms, including alterations in the composition and structure of tumor cell membranes, effects on eicosanoid biosynthesis or intracellular signaling pathways, beneficial influence on cellular oxidative stress and DNA damage, and modulation of the immune system or gene expression (38-41). Menendez et al. have recently revealed that OA suppressed the overexpression of HER2 (erbB-2), a well-characterized oncogene playing a key role in the etiology, invasive progression and metastasis in several human cancers $(41,42)$. They have found that OA directly affected the expression of a cluster of interrelated human cancer genes (i.e., HER2, FASN and PEA3). However, studies reported higher level of OA in plasma phospholipids of patients with non-Hodgkin lymphoma and obstructive jaundice (including patients with 
hepatocellular carcinoma) than in healthy subjects $(18,21)$, although we believe that these results arised from an altered delta- 9 desaturase activity, rather than an increased intake of oleic acid. Nevertheless, a recent study showed significantly lower intake of olive oil in patients with lung cancer than in the corresponding healthy control subjects (43). Thus an appropriate dietary intervention must be carried out in animal models and human pilot studies to confirm the possible anti-cancer effects of OA.

\section{DIETARY INTAKE OF OLEIC ACID}

In addition to olive oil, another rich source of $\mathrm{OA}$ is rapeseed oil, with $64 \%$ of OA (44), thus we suppose that all health benefits related to olive oil consumption that could be attributed to $\mathrm{OA}$, can also be applied to rapeseed oil consumption. With an average concentration of about $8 \mathrm{~g} / \mathrm{l}$ in whole cow's milk, milk and dairy products substantially contribute to the dietary intake of oleic acid in many countries (45). However, high consumption of milk and/or dairy products is thought to contribute to cardiovascular disease, primarily by increasing saturated fat intake, and for that reason many advisory bodies recommend avoiding high-fat dairy foods (46). Several studies have shown that the percentage of undesirable SFA in cow's milk can be replaced with OA by inclusion of different feed components in cow's nutrition. Komprda et al. have recently shown that feed mixture containing rapeseed, rapeseed oil and rapeseed cakes significantly decreased the content of palmitic acid and increased the content of stearic, oleic, linoleic and $\alpha$-linoleic acid in milk of these cows (47). Another study has demonstrated that supplementation of a basic diet with oilseed, linseed and sunflowerseed improved the milk quality from a nutritional point of view by a large reduction in the content of saturated FA and an increase in the levels of MUFA and PUFA (48). Thus dietary intervention in cows can contribute to healthier milk composition, particularly in terms of its FA content.

Regarding its role in myelinisation, OA is very important in infants' nutrition. Both human milk and infant formulas had significantly higher content of OA than cow's milk (49). Moreover, it is the most abundant FA in breast milk and formulas, and an important source of energy for the infants (7). To provide an optimal content of OA regardless on the diet, only $25 \%$ of OA in breast milk originates from the diet during the past $48 \mathrm{~h}$, while the remaining $75 \%$ originates from the body stores, mostly adipose tissue, or it is produced by interconversion from other FA (50). Nevertheless, Yuhas et al. found different proportions of OA in breast milk from nine countries, which varied from $21.8 \%$ in Philippines to $36.5 \%$ in China, suggesting a significant impact of the diet (12). Although OA is not an essential fatty acid, its content in human milk is of a great importance, because it reduces the melting point of triacylglycerides, thus providing the liquidity required for the formation, transport and metabolism of milk fat globules (51). Higher demands for OA in infancy for brain development suggest that an increased dietary intake of $\mathrm{OA}$ in lactating mothers would enhance nutritional quality of breast milk.

In conclusion, content of oleic acid in serum phospholipids in Serbian population is lower than in Mediterranean countries, but higher than in Northern Europe and it increases during life. Considering beneficial effects of OA, its increased dietary intake would lead to improvement of overall health in the Serbian population.

\section{Acknowledgments}

This paper was supported by the Project 41030 financed by the Ministry of Education, Science and Technological Development.

\section{REFERENCES}

1. Perez-Martinez P, Garcia-Rios A, Delgado-Lista J, Perez-Jimenez F, Lopez-Miranda J: Mediterranean diet rich in olive oil and obesity, metabolic syndrome and diabetes mellitus. Curr Pharm Des 2011; 17(8):769-77.

2. Psaltopoulou T, Naska A, Orfanos P, Trichopoulos D, Mountokalakis T, Trichopoulou A: Olive oil, the Mediterranean diet, and arterial blood pressure: the Greek European Prospective Investigation into Cancer and Nutrition (EPIC) study. Am J Clin Nutr 2004; 80(4):1012-18.

3. Samieri C, Feart C, Proust-Lima C, Peuchant E, Tzourio C, Stapf C, Berr C, Barberger-Gateau P: Olive oil consumption, plasma oleic acid, and stroke incidence: The Three-City Study. Neurology 2011.

4. Visioli F, Galli C: Biological properties of olive oil phytochemicals. Crit Rev Food Sci Nutr 2002; 42(3):209-21.

5. Miraliakbari H, Shahidi F: Oxidative stability of tree nut oils. J Agric Food Chem 2008; 56(12):4751-9.

6. Araujo de Vizcarrondo C CdPF, Martín E: Fatty acid composition of beef, pork, and poultry fresh cuts, and some of their processed products. Arch Latinoam Nutr 1998; 48(3):354-8.

7. Sahin N, Akoh CC, Karaali A: Human milk fat substitutes containing omega-3 fatty acids. J Agric Food Chem 2006; 54(10):3717-22.

8. Rioux FM, Innis SM: Oleic acid (18:1) in plasma, liver and brain myelin lipid of piglets fed from birth with formulas differing in 18:1 content. J Nutr 1992; 122(7):1521-8.

9. Fidler N, Koletzko B: The fatty acid composition of human colostrum. Eur J Nutr 2000; 39(1):31-7.

10. Wu TC, Lau BH, Chen PH, Wu LT, Tang RB: Fatty acid composition of Taiwanese human milk. J Chin Med Assoc 2010; 73(11):581-8.

11. Ribeiro M, Balcao V, Guimaraes H, Rocha G, Moutinho C, Matos C, Almeida C, Casal S, Guerra A: Fatty acid profile of human milk of Portuguese lactating women: prospective study from the 1st to the 16th week of lactation. Ann Nutr Metab 2008; 53(1):50-6. 
12. Yuhas R, Pramuk K, Lien EL: Human milk fatty acid composition from nine countries varies most in DHA. Lipids 2006; 41(9):851-8.

13. Bartl K, Gomez CA, Garcia M, Aufdermauer T, Kreuzer M, Hess HD, Wettstein HR: Milk fatty acid profile of Peruvian Criollo and Brown Swiss cows in response to different diet qualities fed at low and high altitude. Arch Anim Nutr 2008; 62(6):468-84.

14. Tepsic J, Vucic V, Arsic A, Blazencic-Mladenovic V, Mazic S, Glibetic M: Plasma and erythrocyte phospholipid fatty acid profile in professional basketball and football players. Eur J Appl Physiol 2009; 107(3):359-65.

15. Katan MB, Deslypere JP, van Birgelen AP, Penders $M$, Zegwaard M: Kinetics of the incorporation of dietary fatty acids into serum cholesteryl esters, erythrocyte membranes, and adipose tissue: an 18-month controlled study. J Lipid Res 1997; 38(10):2012-22.

16. Popović T, Borozan, S., Arsić, A., Debeljak-Martačić, J., Vučić, V., de Luka, S., Milovanović, I., Trbović, A., Glibetić M: Effects of n-3 Supplementation on Plasma and Liver Phospholipid Fatty Acids Profile in Aged Wistar Rats Croatica Chemica Acta 2011; 84(1):73-9.

17. Arsic A, Vucic V, Prekajski N, Tepsic J, Ristic-Medic D, Velickovic V Glibetic M. Different fatty acid composition of serum phospholipids of small and appropriate for gestational age preterm infants and of milk from their mothers. Hippokratia 2012; 16(3): 230-35.

18. Cvetkovic Z, Vucic V, Cvetkovic B, Petrovic M, RisticMedic D, Tepsic J, Glibetic M: Abnormal fatty acid distribution of the serum phospholipids of patients with non-Hodgkin lymphoma. Ann Hematol 2010; 89(8): 775-82.

19. Tepsic J, Vucic V, Arsic A, Mazic S, Djelic M, Glibetic M. Unfavourable plasma and erythrocyte phospholipid fatty acid profile in elite amateur boxers. Eur J Sport Sci 2013; 13:414-21.

20. Arsic A, Vucic V, Tepsic J, Mazic S, Djelic M, Glibetic M. Altered plasma and erythrocyte phospholipid fatty acid profile in elite female water polo and football players. Appl Physiol Nutr Metab 2012; 37(1): 40-7.

21. Popovic T, Ranic M, Bulajic P, Milicevic M, Arsic A, Vucic V, Glibetic M. Effects of n-3 Fatty Acids Supplementation on Plasma Phospholipids Fatty Acid Composition in Patients with Obstructive Jaundice- a Pilot Study. J Clin Biochem Nutr 2009; 45(3): 370-5.

22. Ristić V, Tepsić V, Ristić-Medié D, Perunicić G, Rasić Z, Postić M, Arsić A, Blazencić-Mladenović V, Ristić G. Plasma and erythrocyte phospholipid fatty acids composition in Serbian hemodialyzed patients. Ren Fail 2006; 28(3): 211-6.

23. Petrovic S, Arsic A, Glibetic M, Cikiriz N, Jakovljevic $\mathrm{V}$, Vucic V. The effects of polyphenol-rich chokeberry juice on fatty acid profiles and lipid peroxidation of active handball players: results from a randomized, double-blind, placebo-controlled study. Can J Physiol Pharmacol 2016; 94(10): 1058-63.
24. Ristic-Medic D, Suzic S, Vucic V, Takic M, Tepsic J, Glibetic M: Serum and erythrocyte membrane phospholipids fatty acid composition in hyperlipidemia: effects of dietary intervention and combined diet and fibrate therapy. Gen Physiol Biophys 2009; 28 Spec No:190-9.

25. Ristić Medić D, Ristić V, Arsić A, Postić M, Ristić G, Blazencić Mladenović V, Tepsić J. Effects of soybean DLeciVita product on serum lipids and fatty acid composition in type 2 diabetic patients with hyperlipidemia. Nutr Metab Cardiovasc Dis 2006; 16(6): 395-404.

26. Ristić-Medić D, Takić M, Vučić V, Kandić D, Kostić $\mathrm{N}$, Glibetić M. Abnormalities in the serum phospholipids fatty acid profile in patients with alcoholic liver cirrhosis - a pilot study. J Clin Biochem Nutr 2013; 53(1): 49-54.

27. Veselinovic M, Vasiljevic D, Vucic V, Arsic A, Petrovic S, Tomic-Lucic A, Savic M, Zivanovic S, Stojic V, Jakovljevic V. Clinical Benefits of n-3 PUFA and $\gamma$-Linolenic Acid in Patients with Rheumatoid Arthritis. Nutrients 2017; 9(4). pii: E325. doi: 10.3390/nu9040325.

28. Pauwels EK: The protective effect of the Mediterranean diet: focus on cancer and cardiovascular risk. Med Princ Pract 2011; 20(2):103-11.

29. Kris-Etherton PM, Pearson TA, Wan Y, Hargrove RL, Moriarty K, Fishell V, Etherton TD: High-monounsaturated fatty acid diets lower both plasma cholesterol and triacylglycerol concentrations. Am J Clin Nutr 1999; 70(6):1009-15.

30. Lopez-Miranda J, Perez-Jimenez F, Ros E, De Caterina R, Badimon L, Covas MI, Escrich E, Ordovas JM, Soriguer F, Abia R et al: Olive oil and health: summary of the II international conference on olive oil and health consensus report, Jaen and Cordoba (Spain) 2008. Nutr Metab Cardiovasc Dis 2010; 20(4):284-94.

31. Granados N, Amengual J, Ribot J, Palou A, Bonet ML: Distinct effects of oleic acid and its trans-isomer elaidic acid on the expression of myokines and adipokines in cell models. Br J Nutr 2011; 105(8):1226-34.

32. Kien CL: Dietary interventions for metabolic syndrome: role of modifying dietary fats. Curr Diab Rep 2009; 9(1):43-50.

33. Lopez-Huertas E: Health effects of oleic acid and long chain omega-3 fatty acids (EPA and DHA) enriched milks. A review of intervention studies. Pharmacol Res 2010; 61(3):200-7.

34. Mensink RP, Zock PL, Kester AD, Katan MB: Effects of dietary fatty acids and carbohydrates on the ratio of serum total to HDL cholesterol and on serum lipids and apolipoproteins: a meta-analysis of 60 controlled trials. Am J Clin Nutr 2003; 77(5):1146-55.

35. Pedersen A, Baumstark MW, Marckmann P, Gylling H, Sandstrom B: An olive oil-rich diet results in higher concentrations of LDL cholesterol and a higher number of LDL subfraction particles than rapeseed oil and sunflower oil diets. J Lipid Res 2000; 41(12):1901-11. 
36. Saadatian-Elahi M, Slimani N, Chajes V, Jenab $M$, Goudable J, Biessy C, Ferrari P, Byrnes G, Autier P, Peeters PH et al: Plasma phospholipid fatty acid profiles and their association with food intakes: results from a cross-sectional study within the European Prospective Investigation into Cancer and Nutrition. Am J Clin Nutr 2009; 89(1):331-46.

37. Hodge AM, Simpson JA, Gibson RA, Sinclair AJ, Makrides M, O’Dea K, English DR, Giles GG: Plasma phospholipid fatty acid composition as a biomarker of habitual dietary fat intake in an ethnically diverse cohort. Nutr Metab Cardiovasc Dis 2007; 17(6):415-26.

38. Binukumar B, Mathew A: Dietary fat and risk of breast cancer. World J Surg Oncol 2005; 3:45.

39. Bartsch H, Nair J, Owen RW: Dietary polyunsaturated fatty acids and cancers of the breast and colorectum: emerging evidence for their role as risk modifiers. Carcinogenesis 1999; 20(12):2209-18.

40. Escrich E, Moral R, Grau L, Costa I, Solanas M: Molecular mechanisms of the effects of olive oil and other dietary lipids on cancer. Mol Nutr Food Res 2007; 51(10):1279-92.

41. Menendez JA, Lupu R: Mediterranean dietary traditions for the molecular treatment of human cancer: anti-oncogenic actions of the main olive oil's monounsaturated fatty acid oleic acid (18:1n-9). Curr Pharm Biotechnol 2006; 7(6):495-502.

42. Menendez JA, Papadimitropoulou A, Vellon L, Lupu R: A genomic explanation connecting "Mediterranean diet", olive oil and cancer: oleic acid, the main monounsaturated fatty acid of olive oil, induces formation of inhibitory "PEA3 transcription factor-PEA3 DNA binding site" complexes at the Her-2/neu (erbB-2) oncogene promoter in breast, ovarian and stomach cancer cells. Eur J Cancer 2006; 42(15):2425-32.
43. Stojanović A, Zeković M, Rašić-Milutinović Z, RistićMedić D, Pokimica, Debeljak-Martačić J, Vučić Vesna: Dietary intake in newly diagnosed lung cancer patients. Srp arh celok lek, 2017; doi.org/10.2298/SARH170301115S

44. Vucic V, Tepsic J, Arsic A, Popovic T, Debeljak-Martacic J, Glibetic M. Fatty Acid Content of Vegetable Oils and Assessment of Their Consumption in Serbia. Acta Aliment 2012; 41:343-50.

45. Haug A, Hostmark AT, Harstad OM: Bovine milk in human nutrition--a review. Lipids Health Dis 2007; 6:25.

46. Lichtenstein AH, Appel LJ, Brands M, Carnethon M, Daniels S, Franch HA, Franklin B, Kris-Etherton P, Harris WS, Howard B et al: Diet and lifestyle recommendations revision 2006: a scientific statement from the American Heart Association Nutrition Committee. Circulation 2006; 114(1):82-96.

47. Komprda T, Zelenka J, Fajmonova E, Fialova M, Kladroba D: Arachidonic acid and long-chain $\mathrm{n}-3$ polyunsaturated fatty acid contents in meat of selected poultry and fish species in relation to dietary fat sources. J Agric Food Chem 2005; 53(17):6804-12.

48. Collomb M, Sieber R, Butikofer U: CLA isomers in milk fat from cows fed diets with high levels of unsaturated fatty acids. Lipids 2004; 39(4):355-64.

49. Arsić A, Prekajski N, Vučić V, Tepsić J, Popović T, Vrvić M, Glibetić M. Milk in human nutrition: comparison of fatty acid profiles. Acta vet (Beograd) 2009; 59:569-78.

50. Fidler N, Sauerwald T, Pohl A, Demmelmair H, Koletzko B: Docosahexaenoic acid transfer into human milk after dietary supplementation: a randomized clinical trial. J Lipid Res 200; 41(9):1376-83.

51. Jensen RG, Lammi-Keefe CJ, Henderson RA, Bush VJ, Ferris AM: Effect of dietary intake of n-6 and n-3 fatty acids on the fatty acid composition of human milk in North America. J Pediatr 1992; 120(4 Pt 2):S87-92. 